\title{
男女大学生の甘味嗜好と食生活に関する意識調査
}

\author{
加藤征江 $*$. 山路恵子* . 小谷スミ子** \\ $(*$ 富山大学教育学部, **新潟大学教育学部)
}

\section{Survey Regarding Sweet Taste Preference and Dietary Life of Male and Female Students}

\author{
Yukie Kato*, Keiko Yamazi*, and Sumiko Odani** \\ * Faculty of education, Toyama University, 3190 \\ Gohuku, Toyama-shi, Toyama, 930-8555 \\ * * Faculty of education, Niigata University, 8050 \\ Igarasi 2nomati, Niigata-shi, Niigata, 950-2181 \\ 于930-8555 富山市五福9130 \\ テ950-2181 新潟市五十嵐二の町 8050
}

In order to investigate how the sweetness preference affects the situation and consciousness of dietary life among the younger generation, we surveyed male and female students (300 males, 298 females) using a questionaire. The results were as follows.

1) As for the sweetness preference, "the intake frequency of sweet confectionery" was strongly correlated with each of the intake frequencies for six kinds of confectioneries. Also, the "favorite concentration of sweet drink" was strongly correlated with each preference degree for two kinds of sweet drinks.

2) The at-home group showed a rather higher intake frequency for sweet confectionery, compared with the group living out of the house for both the male and female students. The sport activity group had a higher intake frequency for sweet drinks than the other groups, especially for the males.

3) The "intake frequency of breakfast" was the lowest of the three meals. Especially, $41.3 \%$ of the male students always skipped breakfast. Also for the males, the group that skipped breakfast had a lower intake frequency for sweet confectioneries and sweet drinks in addition to the meal than the group taking it every day.

4) For the famales, it was significantly noted that the groups doing biased dieting had a lower intake frequency for sweet drinks and also that the groups thinking of a nutritional balance liked the thinner taste for sweet drinks.

5) Based on an analysis using Hayashi's Quantification Method 1, the degree which the sweetness preference concerns the "degree of satisfaction of dietary life" wasn't as strong as much the "intake frequency of breakfast" and "nutritional balance". The groups with a higher intake frequency for sweet confectionery had, if anything a lower degree for satisfaction for dietary life. Also, for the males, groups liking a thicker taste for sweet drinks and for the female, groups liking a rather thinner taste for sweet drinks 
had a higher degree for satisfaction for dietary life.

\section{1. 緒言}

近年, 若者の食の乱れが危惧され，そのため彼らの食 生活と健康について居住形態との関連 ${ }^{1)}$, 2)，ライフス タイルとの関連3) など諸々の観点から研究されている が，甘い食物の摂取の観点からみた報告はあまりない。

最も甘い砂糖自体はエネルギー源であって体に悪いこと はないが，それの過度の摂取が食生活に悪影響した場合 が問題となってくると思われる.

我々は，これまでに人間の生体生理と深く関係のある 塩味と甘味について, 男女大学生を対象に, 味覚意識と 食物嗜好の関連についての調査 ${ }^{4)}$ ，およびそれら両味の 味覚検査による味嗜好（味の嗜好濃度）と調査による食 物の嗜好との関連について5）調べてきた。

そこで，本報告では男女大学生を対象に，食生活と健 康について考えるために，甘いお菓子の摂取頻度および 甘い飲久物の嗜好濃度が食生活状況や食生活意識といか に関わるかを明らかにすることを目的として調査を行 い，若干の知見を得たので報告する.

\section{2. 方 法}

\section{(1) 対象，期日，実施方法}

平成 8 年 $6 \sim 9$ 月に, 食生活のアンケート調査を北陸 地方の 2 大学の学生, 男子 329 人と女子 332 人に対して, 質問紙を配布し, 記入後, 直ちに回収した. そのうち有 効回答数は男子 300 人（有効回答率 $91.2 \%$ ), 女子 298 人。 (同89.8\%) であった.

\section{(2) 調査内容}

学生の属性については表 1 に示したように居住形態と 部活動の 2 項目を調べた。甘味に関しては甘いお菓子の 摄取頻度と甘い飲み物の嗜好濃度の 2 項目および具体的 な甘いお菓子や甘い飲み物についての 8 項目，そして食 生活状況・意識については 7 項目を取り上げた。 それら の各項目は単数回答とした. また甘味に関する項目との 関連から，間食理由と主な飲み物についての項目も取り

\section{表 1 対象者の属性}

\begin{tabular}{l|l|rr|rr}
\hline \multirow{2}{*}{ 項 目 } & \multirow{2}{*}{ カテゴリー } & \multicolumn{2}{|c|}{ 男子 $(300$ 人) } & \multicolumn{2}{|c}{ 女子 $(298$ 人) } \\
\cline { 3 - 7 } & & 人数 & $\%$ & 人数 & $\%$ \\
\hline \multirow{2}{*}{ 居住形態 } & 1.自宅 & 58 & 19.3 & 112 & 37.6 \\
& 2. 寮・アパート & 242 & 80.7 & 186 & 62.4 \\
\hline \multirow{3}{*}{ 部活動 } & 1. 運動部 & 136 & 45.3 & 137 & 45.9 \\
& 2. 文化部 & 59 & 19.7 & 50 & 16.8 \\
& 3. 入部せず & 96 & 32.0 & 100 & 33.6 \\
\hline
\end{tabular}

$166(70)$
上げたが，これらは複数回答とした。

\section{(3) 統計処理}

調査データはパソコンの統計ソフト（社会情報サービ スK.K.）を用いて，集計および統計処理した．各項目の カテゴリ一回答のものは単純集計, クロス集計とカイ 2 乗検定をし，また項目によってはカテゴリ一回答のもの を数量化して, 平均値と標準偏差, 相関分析を行った. また食生活状況と甘いものに関する項目の関係をみるた め, 多変量解析の一つ, 数量化 1 類による分析 ${ }^{6)}$ 女試み た。

\section{3．結果と考察}

\section{（1）甘味嗜好の実態}

甘味嗜好としては,「甘いお菓子の摂取頻度」と「甘 い飲み物の嗜好濃度」をとりあげて, 学生の実態を調べ た. 先ず，学生の「甘いお菓子の摂取頻度」について表 2 よりみると, “毎日 2 回以上”と“毎日 1 回位”とを 合わせると, 男子では約 $20 \%$, 女子では約 40\%弱となる. この 5 段階評価のカテゴリーを数量（摂取頻度の高い “毎日 2 回以上”を 5 点とし, “めったに食べない”を 1 点）に変換し，また具体的なお菓子 6 種類の摂取頻度 も同様のスケールの数量で評価した時の平均值と標準偏 差を示したのが表 3 の(1)である.「甘いお菓子の摂取頻 度」の平均値は男子では2.70（標準偏差1.04）, 女子で は3.13（標準偏差0.91）となり，男女間に有意な差（p <0.01）があり，女子の方の摂取頻度は高かった．具体 的な 6 種類のお菓子の摂取頻度でも, スナック菓子以外 の甘いお菓子類の摂取頻度は女子の方がやや評価の平均 值は高かった. そして表 3 の(2)には「甘いお菓子の摂取 頻度」と具体的な 6 種類のお菓子の摂取頻度との相関係 数を示したが，それらの間はいずれの組み合わせも，男 女ともに有意に高いことから，以後の分析において，具 体的な甘いお菓子の摂取頻度を「甘いお菓子の摂取頻度」 の項目で代表させた.

一方,「甘い飲み物の嗜好濃度」については表 2 に示 したが，この項目は男女間で有意な差がみられず，男子 の方が女子よりもやや濃い味嗜好であり，このことは既 報4) と同様であった。この「甘い飲み物の嗜好濃度」も 5 段階評価のカテゴリーを数量に変換し（“濃い方が好 き”〜“薄い方が好き”を $5 \sim 1$ 点とした)，そして具 体的な甘い飲み物として, 紅茶やコーヒ（嗜好飲料）と 甘味飲料（市販の甘味をもったジュースなど）の 2 種類 
表 2 甘味に関する項目と食生活に関する項目

\begin{tabular}{|c|c|c|c|c|c|c|c|}
\hline \multirow{2}{*}{ 分類 } & \multirow{2}{*}{ 項目 } & \multirow{2}{*}{ カテゴリー } & \multicolumn{2}{|c|}{ 男子（300人) } & \multicolumn{2}{|c|}{ 女子（298人) } & \multirow{2}{*}{$\begin{array}{l}\text { 男女間 } \\
\text { の差*2 }\end{array}$} \\
\hline & & & 人数 & $\%$ & 人数 & $\%$ & \\
\hline \multirow{10}{*}{$\begin{array}{l}\text { 甘味 } \\
\text { 嗜好 }\end{array}$} & 1.甘い & 1. 毎日 2 回以上 & 8 & 2.7 & 5 & 1.7 & \\
\hline & お菓子の & 2.毎日 1 回位 & 56 & 18.7 & 110 & 36.9 & \\
\hline & 摂取頻度 & $3.2 \sim 3$ 日に 1 回位 & 126 & 41.9 & 120 & 40.2 & $* *$ \\
\hline & & $4.1 \sim 2$ 週間に 1 回位 & 59 & 19.7 & 44 & 14.8 & \\
\hline & & 5.めったに食べない & 51 & 17.0 & 19 & 6.4 & \\
\hline & 2.甘い & 1.濃い方が好き & 20 & 6.7 & 12 & 4.0 & \\
\hline & 読み物の & 2.やや濃い方が好き & 81 & 27.0 & 67 & 22.5 & \\
\hline & 嗜好濃度 & 3.どちらともいえない & 127 & 42.3 & 154 & 51.7 & - \\
\hline & & 4.やや薄い方が好き & 58 & 19.3 & 53 & 17.8 & \\
\hline & & 5.薄い万が好き & 14 & 4.7 & 12 & 4.0 & \\
\hline \multirow{9}{*}{$\begin{array}{c}\text { 三食の } \\
\text { 摂取 } \\
\text { 頻度 }\end{array}$} & 3.朝食の & 1.毎日食べる & 78 & 26.0 & 173 & 58.0 & \\
\hline & 摂取頻度 & 2.時々食べない & 98 & 32.7 & 101 & 33.9 & $* *$ \\
\hline & & 3.いつも食べない & 124 & 41.3 & 24 & 8.1 & \\
\hline & 4.昼食の & 1.毎日食べる & 211 & 70.4 & 260 & 87.2 & \\
\hline & 摂取頻度 & 2.時々食べない & 82 & 27.3 & 38 & 12.8 & $* *$ \\
\hline & & 3.いつも食べない *1 & 7 & 2.3 & 0 & 0.0 & \\
\hline & 5.夕食の & 1.毎日食べる & 261 & 87.0 & 243 & 81.6 & \\
\hline & 摂取頻度 & 2.時々食べない & 39 & 13.0 & 54 & 18.1 & - \\
\hline & & 3.いらも食べない＊1 & 0 & 0.0 & 1 & 0.3 & \\
\hline \multirow{8}{*}{$\begin{array}{l}\text { 食事 } \\
\text { 状況 }\end{array}$} & 6.偏食の & 1.ほとんどない & 162 & 54.0 & 132 & 44.3 & \\
\hline & 有無 & 2.少しある & 113 & 37.7 & 131 & 44.0 & * \\
\hline & & 3.非常にある & 25 & 8.3 & 35 & 11.7 & \\
\hline & 7. 食事量 & 1.多い & 21 & 7.0 & 10 & 3.4 & \\
\hline & & 2.やや多い & 84 & 28.0 & 53 & 17.8 & \\
\hline & & 3. 人並み & 145 & 48.3 & 215 & 72.1 & $* *$ \\
\hline & & 4.やや少ない & 39 & 13.0 & 16 & 5.4 & \\
\hline & & 5.少ない & 11 & 3.7 & 4 & 1.3 & \\
\hline \multirow{9}{*}{$\begin{array}{c}\text { 食生活 } \\
\text { に対する } \\
\text { 意識 }\end{array}$} & 8.栄養バ & 1.よく考えている & 12 & 4.0 & 16 & 5.4 & \\
\hline & ランス & 2.考えている & 92 & 30.7 & 152 & 51.0 & $* *$ \\
\hline & & 3.あまり考えていない & 152 & 50.6 & 119 & 39.9 & \\
\hline & & 4.全く考えていない & 44 & 14.7 & 11 & 3.7 & \\
\hline & 9. 食生活 & 1. 満足している & 31 & 10.3 & 48 & 16.1 & \\
\hline & 満足度 & 2.やや満足している & 33 & 11.0 & 40 & 13.4 & \\
\hline & & 3.普通 & 109 & 36.4 & 91 & 30.6 & - \\
\hline & & 4.やや不満である & 91 & 30.3 & 87 & 29.2 & \\
\hline & & 5.不満である & 36 & 12.0 & 32 & 10.7 & \\
\hline
\end{tabular}

*1 検定時には, カテゴリー統合した（カテゴリー 2 と 3 とを合わせた）.

*2 力イ 2 乗検定による. $-\mathrm{n} . \mathrm{s} .,{ }^{*} \mathrm{p}<0.05,{ }^{* *} \mathrm{p}<0.01$.

について摂取頻度（前述に同じ．5〜1点とした）と嗜 好度を数量で評価した（“好き”〜“嫌い”を $5 \sim 1$ 点 とした）時の平均値と標準偏差を示したのが表 4 の(1)で ある. 具体的な 2 種類の甘い飲み物のいずれも，その摂 取頻度および嗜好度とも男女間で有意な差（ $p<0.01 ）$ がみられ，男子が女子よりも評価は高かった，一方，表 4 の(2)には「甘い飲み物の嗜好濃度」とそれら具体的な 2 種類の飲み物の摂取頻度および嗜好度との相関係数を 示したが,「甘い飲み物の嗜好濃度」は具体的な甘い飲
み物の嗜好度とのみ有意に順相関し, それらの間に関連 がみられた。 それで「甘い飲み物の嗜好濃度」を具体的 な甘い飲み物に対する嗜好度（好き〜嫌い）の代表とし て捉えて行くことにした.

これら甘いお菓子や飲み物は間食として摂取すること が多いので，その「間食の理由」を複数回答で調べたの が図 1 である. 全般的に女子の方の回答数が多かった。 間食の理由の高いものについては, 男女ともに“お腹が すいた時”，“目の前にあった時”などであった。これら 
(1) 平均値と標準偏差

表 3 甘いお菓子と各お菓子の摄取頻度の関係

\begin{tabular}{|c|c|c|c|c|}
\hline 項目 & 男子 $(300$ 人) & 女子(298人) & 男女間*2 & \\
\hline 甘いお菓子の摂取頻度 & $2.70 \pm 1.04$ & $3.13 \pm 0.91$ & ** & \\
\hline ようかん・䡬頭の摂取頻度 & $1.38 \pm 0.67$ & $1.49 \pm 0.75$ & $=$ & \\
\hline チョコレートの摂取頻度 & $2.00 \pm 0.94$ & $2.48 \pm 0.96$ & ** & \\
\hline クッキーの摂取頻度 & $1.78 \pm 0.84$ & $2.23 \pm 0.96$ & ** & \\
\hline ケーキの摂取頻度 & $1.44 \pm 0.67$ & $1.65 \pm 0.70$ & ** & \\
\hline スナック菓子の摂取頻度 & $2.24 \pm 0.87$ & $2.08 \pm 0.88$ & - & \\
\hline アイスクリームの摂取頻度 & $2.83 \pm 1.06$ & $3.14 \pm 0.94$ & $* *$ & \\
\hline \multirow{2}{*}{\multicolumn{5}{|c|}{ 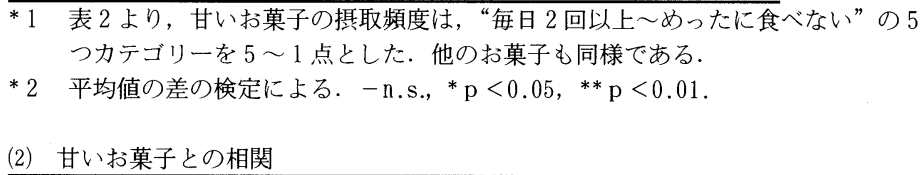 }} \\
\hline & & & & \\
\hline \multirow[t]{2}{*}{ 項 目 } & \multicolumn{2}{|c|}{ 男子 (300人) } & \multicolumn{2}{|c|}{ 女子 $(298$ 人) } \\
\hline & 相関値 $(r)$ & 検定*1 & 相関値 $(r)$ & 検定*1 \\
\hline ようかん・饅頭の摂取頻度 & 0.314 & ** & 0.314 & $* *$ \\
\hline チョコレートの摂取頻度 & 0.609 & ** & 0.593 & $* *$ \\
\hline クッキーの摂取頻度 & 0.522 & $* *$ & 0.531 & $* *$ \\
\hline ケーキの摂取頻度 & 0.424 & ** & 0.351 & $* *$ \\
\hline スナック菓子の摂取頻度 & 0.410 & $* *$ & 0.310 & $* *$ \\
\hline アイスクリームの摂取頻度 & 0.399 & $* *$ & 0.318 & $* *$ \\
\hline
\end{tabular}

${ }^{* 1}{ }^{* *} \mathrm{p}<0.01$

表 4 甘い飲み物の嗜好濃度と各甘味の飲み物の摄取頻度および嗜好度 (1) 平均値と標準偏差

\begin{tabular}{|c|c|c|c|c|}
\hline 項目 & 男子 (300人) & 女子(298人) & 男女間*2 & \\
\hline 甘い飲み物の嗜好濃度*1 & $3.12 \pm 0.95$ & $3.05 \pm 0.85$ & $\overline{-}$ & \\
\hline 甘味飲料の摂取頻度 & $4.02 \pm 0.90$ & $3.33 \pm 1.22$ & ** & \\
\hline 紅茶・コーヒーの摂取頻度 & $3.17 \pm 1.33$ & $2.80 \pm 1.36$ & $* *$ & \\
\hline 甘味飲料の嗜好度 & $4.23 \pm 0.87$ & $3.52 \pm 1.09$ & ** & \\
\hline 紅茶·コーヒーの嗜好度 & $3.85 \pm 1.16$ & $3.49 \pm 1.23$ & ** & \\
\hline \multirow{2}{*}{\multicolumn{5}{|c|}{ 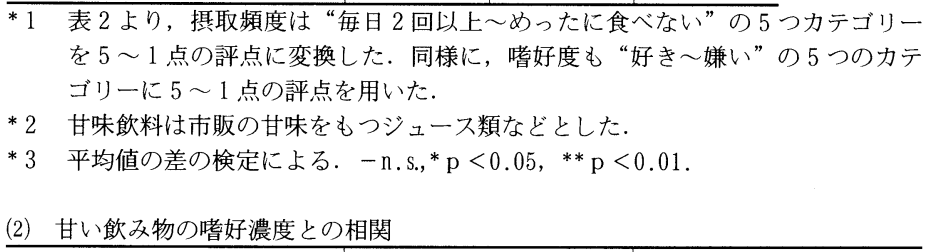 }} \\
\hline & & & & \\
\hline \multirow[t]{2}{*}{ 項目 } & \multicolumn{2}{|c|}{ 男子 (300人) } & \multicolumn{2}{|c|}{ 女子 $(298$ 人) } \\
\hline & 相関値 $(r)$ & 検定*1 & 相関值 ( r ) & 検定*1 \\
\hline 甘味飲料の摂取頻度 & -0.003 & - & 0.089 & - \\
\hline 紅茶・コーヒーの摂取頻度 & 0.108 & - & 0.116 & * \\
\hline 甘味飲料の嗜好度 & 0.154 & $* *$ & 0.137 & $*$ \\
\hline 紅茶·コーヒーの嗜好度 & 0.144 & $* *$ & 0.187 & $* *$ \\
\hline
\end{tabular}

以外の理由としては，男子では“喉が渴いた時”，“なん となく”が挙げられ，女子では“友達に勧められて”,

“疲れた時”，“ストレスがたまった時”，“なんとなく” などが挙げられていた。このような回答数の分布につい ては，カイ 2 乗検定により男女間に有意な差 $(p<0.01)$ がみられた。

男子では特に “喉が渴いた時”などの生理的な理由が
多く，これは表 4 の(1)の甘味飲料に対する摂取頻度や咾 好度は男子の方が高いことと関連すると考えられ，一方， 女子では男子に比べて, “疲れた時”や“ストレスがた まった時”などの理由がかなり多かったが, その時, 甘 いお菓子を摂取することが多いのか, 表 3 の(1)に示した 「甘い摷子の摂取頻度」は女子の方が高い.

この「間食の理由」に関係した項目として，「主な飲

$168(72)$ 


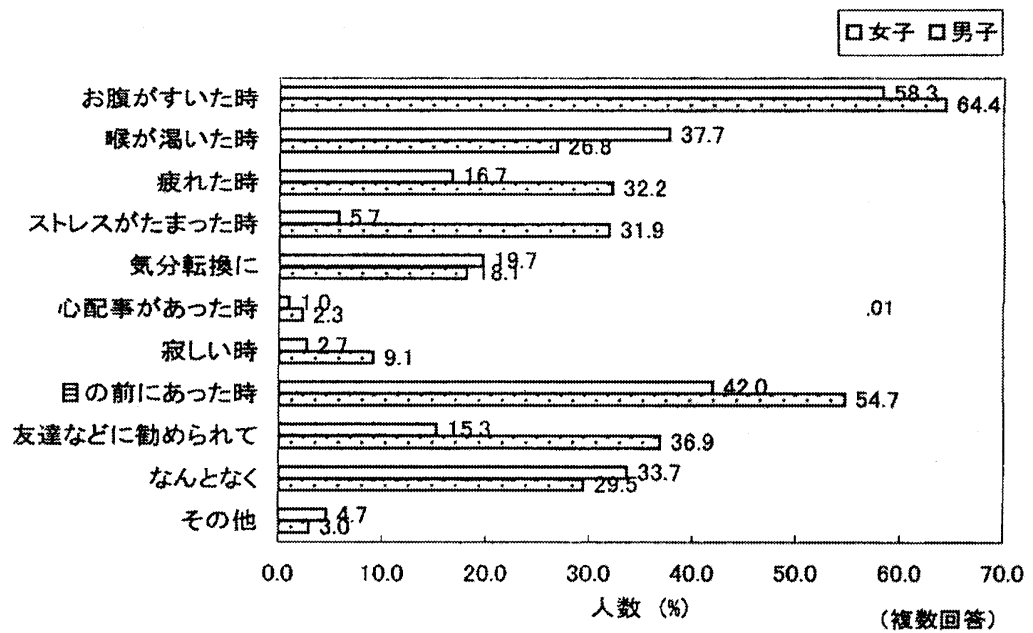

図 1 間食理由について

（注） 1 ．男女間の差はカイ 2 乗検定による. $p<0.01$

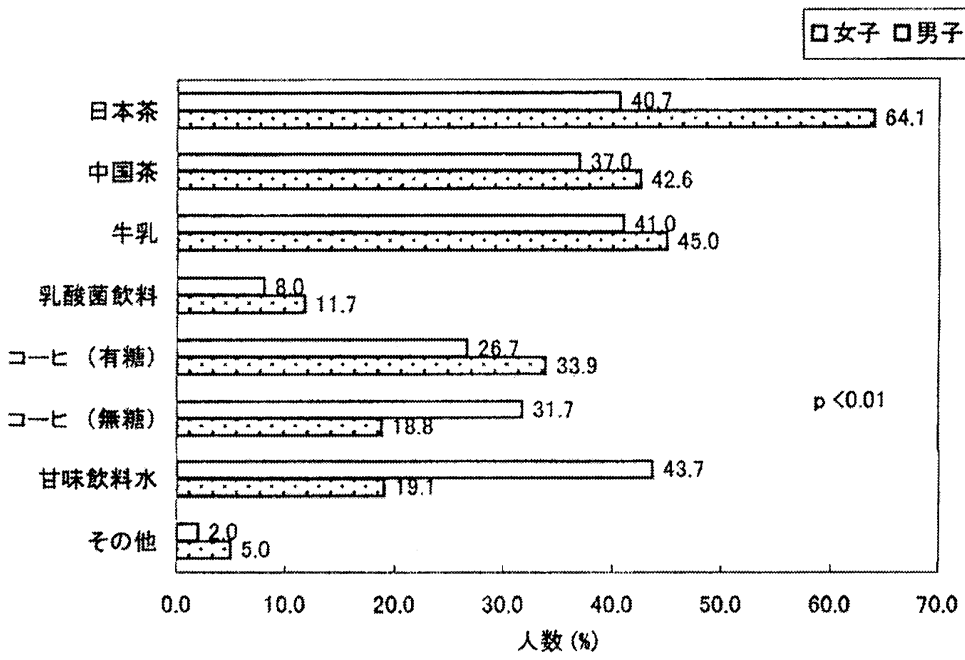

図 2 主な飲み物

(楼数回答)

（注） 1 ．男女間の差はカイ 2 乗検定による. $p<0.01$

み物」を複数回答で調べた結果は図 2 である.これから も男子は「主な飲み物」については, “甘味飲料”が最 も多く, 次いで “日本茶”, “中国茶”, “牛乳”の順であ った. 一方，女子は“日本茶” が極めて多く，次いで “牛乳”, “中国茶”の順にあげられており，それに対し “甘味飲料”とする回答数はかなり少なかった.この回 答数の分布には男女間に有意な差 $(p<0.01)$ があり, 確かに男子と女子とは “甘味飲料”に対する摂取頻度は
異なっていた。これは男女の“甘味飲料”に対する認識 の違い，つまり女子は“甘味飲料”という言葉に対して かなり神経質になっていることも加わってのことかも知 れない.

（2）食生活の状況および意識の実態

次に甘味㖺好に対する食生活状況の関わりを調べるた め, 先ず, 表 2 に示した, 三食の摂取頻度（朝食, 昼食, 夕食), 食事状況 (偏食の有無, 食事量), 食生活に対す 
表 5 甘味に関する項目と他項目との有意差判定

\begin{tabular}{|c|c|c|c|c|c|c|}
\hline \multirow{2}{*}{$\begin{array}{l}\text { 番 } \\
\text { 号 }\end{array}$} & \multirow{2}{*}{$\begin{array}{l}\text { 性 } \\
\text { 別 }\end{array}$} & \multirow[b]{2}{*}{ 分 類 項 目 } & \multicolumn{4}{|c|}{ 集 計 項 目 } \\
\hline & & & $\begin{array}{l}\text { 甘いお菓子 } \\
\text { 掑取頻度 }\end{array}$ & $\begin{array}{l}\text { 甘い飲み物 } \\
\text { 嗜好濃度 }\end{array}$ & $\begin{array}{c}\text { 甘味飲料 } \\
\text { 摂取頻度 }\end{array}$ & 主な飲み物 \\
\hline \multirow[t]{2}{*}{1.} & 男 & 居住形態 & - & - & - & - \\
\hline & 女 & 同 & - & - & - & - \\
\hline \multirow[t]{2}{*}{2.} & 男 & 部活動 & - & - & $* *$ & - \\
\hline & 女 & 同 & - & - & - & - \\
\hline \multirow[t]{2}{*}{3.} & 男 & 朝食の摂取頻度 & - & - & - & - \\
\hline & 女 & 同 & - & - & - & - \\
\hline \multirow[t]{2}{*}{4.} & 男 & 朝食の摂取頻度 & - & - & - & - \\
\hline & 女 & 同 & - & $* *$ & - & - \\
\hline \multirow[t]{2}{*}{5.} & 男 & 夕食の摂取頻度 & - & - & - & - \\
\hline & 女 & 同 & - & - & - & - \\
\hline \multirow[t]{2}{*}{6.} & 男 & 偏食の有無 & - & - & - & - \\
\hline & 女 & 同 & - & - & $* *$ & $* *$ \\
\hline \multirow[t]{2}{*}{7.} & 男 & 食事量 & - & - & - & - \\
\hline & 女 & 同. & - & - & - & - \\
\hline \multirow[t]{2}{*}{8.} & 男 & 栄養バランス & - & - & - & - \\
\hline & 女 & 同 & - & $* *$ & - & $*$ \\
\hline \multirow[t]{2}{*}{9.} & 男 & 食生活の満足度 & - & - & - & - \\
\hline & 女 & 同 & - & - & - & $*$ \\
\hline
\end{tabular}

る意識（栄養バランス, 食生活の満足度）の調査結果を 分析した。

「朝食の拱取頻度」,「昼食の摂取頻度」,「偏食の有無」, 「食事量」,「栄養バランス」においては, 男女間に有意 な差があり，男女は食生活の状況および意識においては かなり差がみられることが分かった．特に男子では「朝 食の摂取頻度」において, “いつも食べない”とする人 は $41.3 \%$ と非常に多く，これを平成 8 年国民栄養調査成績 7$)$ の 20 代男子の朝食欠食率約 $28 \%$ と比べても，その割合が 非常に高かった．これについては居住形態との関連が考 えられ3），表 1 に示したように，本調査における男子の 自宅外生の割合は $80.7 \%$ と非常に高かった．とこで「朝 食の摂取頻度」と「居住形態」とのクロス集計を行った 結果, 自宅生群と自宅外生群との間に朝食の摂取頻度に 有意な差があり $(p<0.01)$, 自宅外生群では, $48 \%$ が “いつも食べない”，33\%が“時々食べない”であり，

“毎日食べる”のは僅か $19 \%$ であった．このように，本 調査における男子学生の朝食欠食率が同年代の男子に比 べ，顕著に高かったのは自宅外生が男子学生の大部分を 占めていたためと思われる.

しかし，「食生活における満足度」においては，男女 間に有意な差はみられず，“満足である”，“やや満足で ある”と“普通”とを合わせると，男女ともに約 $60 \%$ で あり，平成 8 年国民栄養調査の「現在の食生活に対する 評価」8）での“大変よい”と“よい”とを合わせた割合
とほぼ同程度であった。

（3）甘味嗜好と学生生活, 食生活の諸要因との関連 甘味に関する項目として,「甘いお菓子の摂取頻度」, 「甘い飲久物の嗜好濃度」,「甘味飲料の恸取頻度」およ び複数回答で調べた「主な飲み物」の 4 項目について, 学生の生活環境（表 1 に示した居住形態, 部活動）およ び食生活状況（表 2 に示した三食の摂取頻度, 食事状況, 食生活意識）との関連をクロス集計後，カイ 2 乗検定に よって調べた結果を表 5 に示した。これによると「甘い お菓子の摂取頻度」は生活環境や食生活状況のどの項目 とも有意に関連はしなかった。しかし「甘い飲み物の嗜 好濃度」,「甘味飲料の摂取頻度」,「主な飲み物」の 3 項 目は生活環境や食生活状況の幾つかの項目とは有意な関 連を示した. 以下にこのことについて, 生活環境や食生 活状況別に甘味との関わりを検討した.

1) 甘味嗜好と居住形態, 部活動などの学生の生活環 境との関連

居住形態別には自宅外生群の方が甘いお菓子の摂取頻 度が高いのではないかと予想をしていたのであるが，図 3-1の居住形態別甘いお菓子の摂取頻度より，男女とも に自宅生群の方が自宅外生群に比べて, むしろ「甘いお 菓子の摂取頻度」はやや高い傾向がみられたが, それら の関係は有意とまでには至らなかった。

「部活動」との関連については, 表 5 より「部活動」 と「甘味飲料の摂取頻度」とは, 男子では有意となった。 

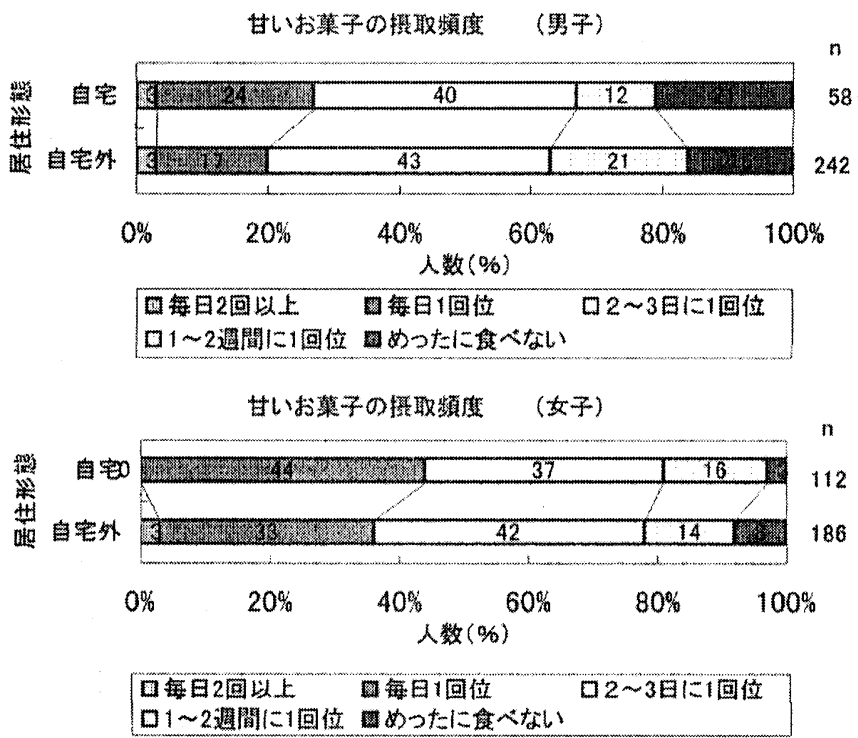

図3-1 居住形態別の甘いお菓子の㩒取頻度
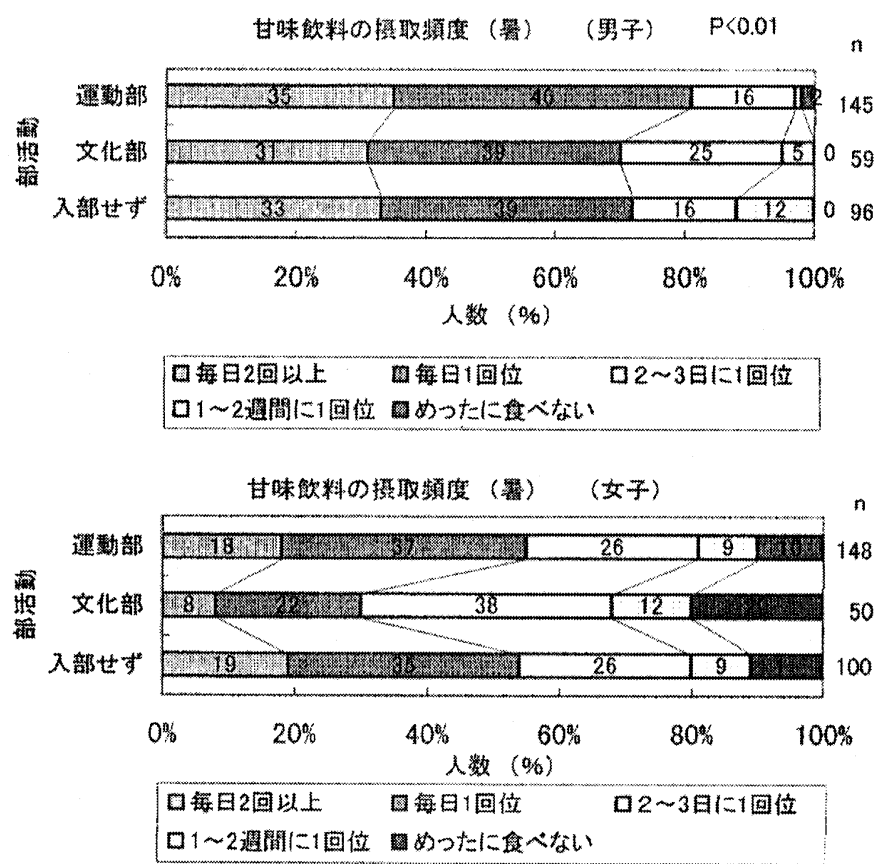

図3-2 部活動別の甘味飲料の摂取頻度

それを図3-2よりみると，男子では，明らかに，運動部 活動群は文化部活動群や入部せず群に比べて，その摂取 頻度は高かった．ところが女子は男子に比べ, 全体的に
「甘味飲料の摂取頻度」は前述したようにかなり低く， しかもそれと「部活動」とのクロスは有意ではなかった が, 男子と同様に一応, 運動部活動群は高い傾向はみら 


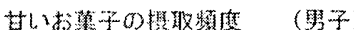
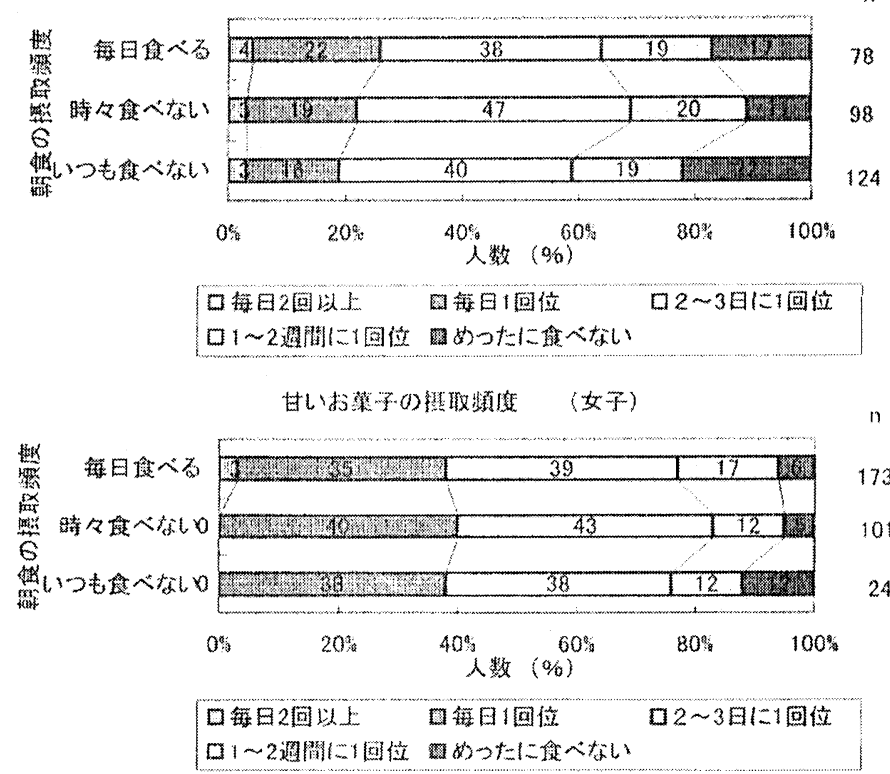

図4-1 朝食の摂取頻度別, 甘いお菓子の摂取頻度
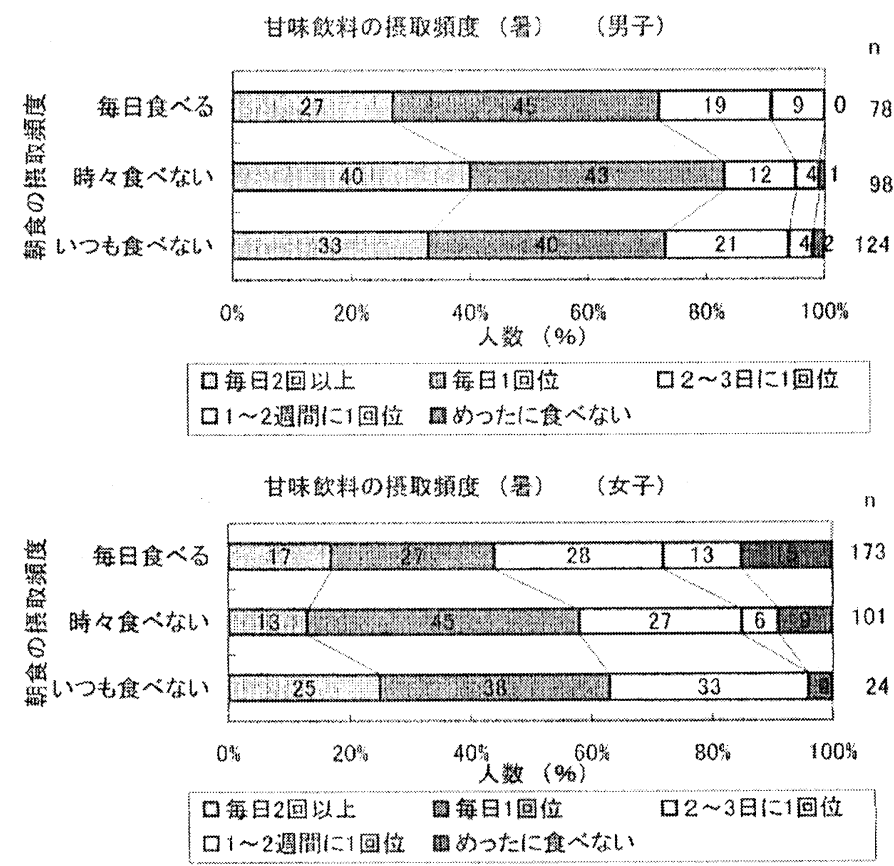

図4-2 朝食の摂取頻度別，甘味飲料の摂取頻度 
表 6 朝食の摂取頻度別および栄養バランス別, 主な飲み物

\begin{tabular}{|c|c|c|c|c|c|c|c|c|c|c|}
\hline \multirow{2}{*}{\multicolumn{2}{|c|}{ 朝食の摂取頻度 }} & \multirow{2}{*}{ 日本茶 } & \multirow{2}{*}{ 中国茶 } & \multirow{2}{*}{ 牛乳 } & \multirow{2}{*}{$\begin{array}{l}\text { 酸乳 } \\
\text { 飲料 }\end{array}$} & \multicolumn{2}{|c|}{ 紅茶·コーヒー } & \multirow{2}{*}{$\begin{array}{ll}\text { 甘味 } & \\
\text { 飲料 *2 }\end{array}$} & \multirow{2}{*}{ その他 } & \multirow{2}{*}{ 全体 } \\
\hline & & & & & & （有糖） & （無糖） & & & \\
\hline \multirow{3}{*}{ 男子 } & 1.毎日食べる & $42(53.8)$ & $28(35.9)$ & $36(46.2)$ & $6(7.7)$ & $23(29.5)$ & $19(24.4)$ & $24(30.8)$ & $0(0.0)$ & $78(100.0)$ \\
\hline & 2.時々食べない & $37(37.8)$ & $33(33.7)$ & $48(49.0)$ & $8(8.2)$ & $26(26.5)$ & $26(26.5)$ & $51(52.0)$ & $2(2.0)$ & $98(100.0)$ \\
\hline & 3.いつも食べない & $43(34.7)$ & $50(40.3)$ & $39(31.5)$ & $10(8.1)$ & $31(25.0)$ & $50(40.3)$ & $56(45.2)$ & $4(3.2)$ & $124(100.0)$ \\
\hline \multirow{3}{*}{ 女子 } & 1.毎日食べる & $114(65.9)$ & $65(37.6)$ & $84(48.6)$ & $17(9.8)$ & $59(34.1)$ & $37(21.4)$ & $26(15.0)$ & $12(6.9)$ & $173(100.0)$ \\
\hline & 2.時々食べない & $60(59.4)$ & $50(49.5)$ & $42(41.6)$ & $12(11.9)$ & $33(32.7)$ & $15(14.9)$ & $23(22.8)$ & $3(3.0)$ & $101(100.0)$ \\
\hline & 3.いつも食べない & $17(70.8)$ & $12(50.0)$ & $8(33.3)$ & $6(25.0)$ & $9(37.5)$ & $4(16.7)$ & $8(33.3)$ & $0(0.0)$ & $24(100.0)$ \\
\hline \multicolumn{11}{|c|}{ 栄䁲バランス } \\
\hline \multirow{4}{*}{ 男子 } & 1.よく考えている & $5(41.7)$ & $4(33.3)$ & $6(50.0)$ & $1(8.3)$ & $2(16.7)$ & $5(41.7)$ & $4(33.3)$ & $1(8.3)$ & $12(100.0)$ \\
\hline & 2.考えている & $41(44.6)$ & $37(40.2)$ & $47(51.1)$ & $7(7.6)$ & $26(28.3)$ & $28(30.4)$ & $44(47.8)$ & $1(1.1)$ & $92(100.0)$ \\
\hline & 3.あまり考えていない & $61(40.1)$ & $54(35.5)$ & $58(38.2)$ & $12(7.9)$ & $42(27.6)$ & $45(29.6)$ & $62(40.8)$ & $2(1.3)$ & $152(100.0)$ \\
\hline & 4.全〈考えていない & $15(34.1)$ & $16(36.4)$ & $12(27.3)$ & $4(9.1)$ & $10(22.7)$ & $17(38.6)$ & $21(47.7)$ & $2(4.5)$ & $44(100.0)$ \\
\hline \multirow{4}{*}{ 女子 } & 1.よく考えている & $9(56.3)$ & $5(31.3)$ & $12(75.0)$ & $1(6.3)$ & $6(37.5)$ & $3(18.8)$ & $3(18.8)$ & $1(6.3)$ & $16(100.0)$ \\
\hline & 2.考えている & $111(73.0)$ & $65(42.8)$ & $76(50.0)$ & $16(10.5)$ & $61(40.1)$ & $20(13.2)$ & $19(12.5)$ & $10(6.6)$ & $152(100.0)$ \\
\hline & 3.あまり考えていない & $66(55.5)$ & $55(46.2)$ & $42(35.3)$ & $15(12.6)$ & $32(26.9)$ & $29(24.4)$ & $31(26.1)$ & $4(3.4)$ & $119(100.0)$ \\
\hline & 4.全く考えていない & $5(45.5)$ & $2(18.2)$ & $4(36.4)$ & $3(27.3)$ & $2(18.2)$ & $4(36.4)$ & $4(36.4)$ & $0(0.0)$ & $11(100.0)$ \\
\hline
\end{tabular}

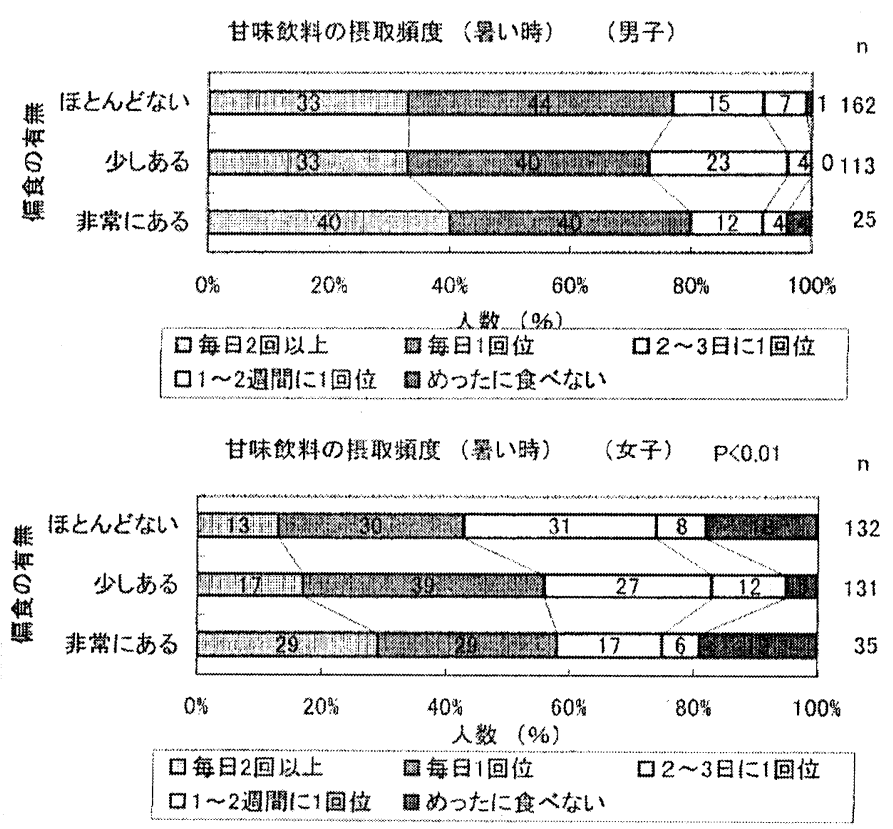

図5-1 偏食の有無別, 甘味飲料摂取頻度 

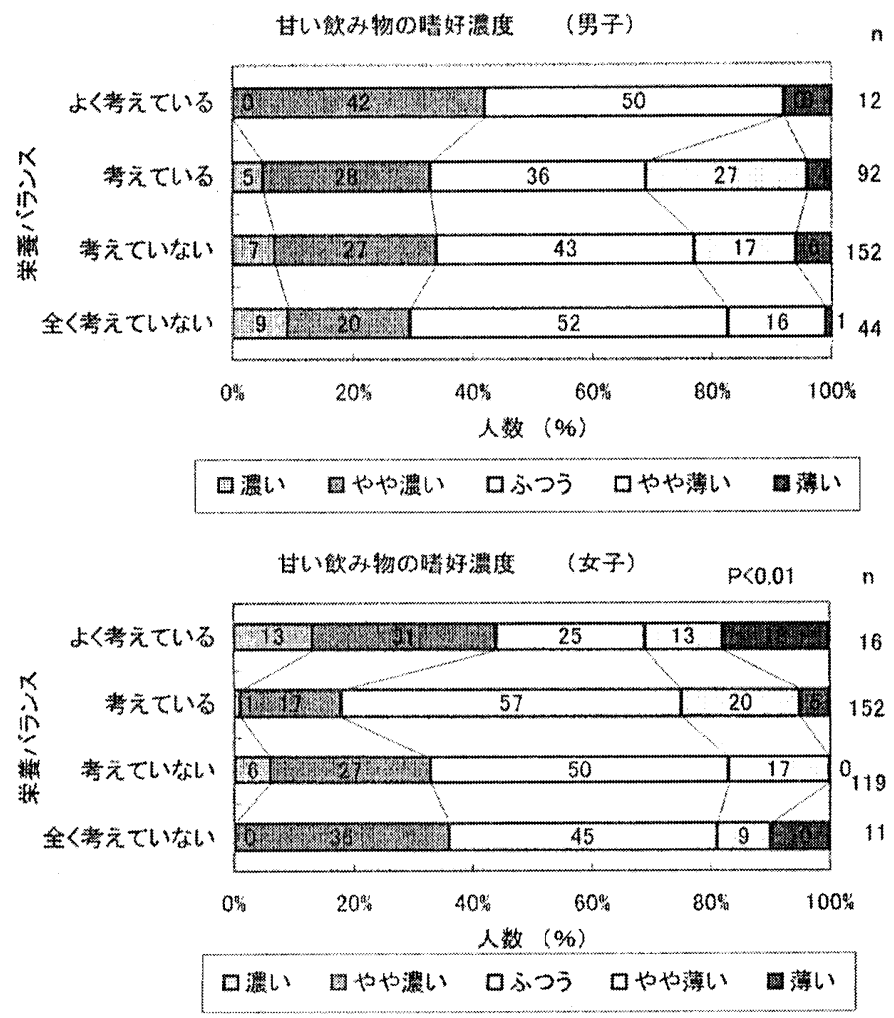

図5-2 栄養バランス別，甘い飲み物の嗜好濃度

れた。ここでも男子に比べ，女子の方の甘味领料に対す る控えめな対応が読及取れた。

\section{2） 甘味嗜好と三食の食事の䎼取頻度との関連}

「朝食の摂取頻度」については表 2 に示した通り，男 子では，前述したように欠食率が非常に高く，かなり問 題であった。それに対し女子では“時々食べない”は $33.9 \%$ ，“いつも食べない”は8.1\%と男子に比べ，かな り低い割合であった。このような朝食欠食群は甘い打菓 子や飲み物の撕取頻度は高いのであろうか，そこでそれ らの関わり具合を詳しくみるために, 図 4 および表 6 に 示したクロス集計の結果より検討する．それで男子の朝 食欠食率が非常に高かったので，男子についてみると図 4-1の「朝食の掑取頻度」と「甘い敃菓子の摂取頻度」 とのクロスから，欠食群（時々食べない，およびいつも 食べない）渄欠食（毎日食べる）群に比べて，むしろ 「甘いお菓子の掑取頻度」はやや低かった。しかし, 図 4-2の「朝食の摄取頻度」と「甘味飲料の摄取頻度」と のクロスでは，図4-1の「甘いお菓子の摂取頻度」とは 多少異なり，次食群の方が「甘味飲料の摂取頻度」がや や高い傾向はみられ，また表 6 の「朝食の摂取頻度」と
「主な飲み物」とのクロスでも，欠食群の方は甘味飲料 を選ぶ割合はやや高い傾向がみられた。しかしながら表 5 に示したように，「朝食の摂取頻度」は甘いものに関 する項目（「甘い抢菓子の摂取頻度」，「甘い飲久物の喍 好濃度」,「甘味飲料の摂取頻度」「主な飲々物」）のいず れとも，男女ともに有意には関連しなかった。

このようなことから, 男子の「朝食の摂取頻度」につ いては, 久食群のうち, 特に “いつも食べない”群は朝 食を摂らないのみでなく,「甘い抢菓子の摄取頻度」や 「甘味飲料の摂取頻度」もそれほど高くはなく, しかも 「主な飲み物」としては栄養的にすぐれた“牛乳”, “乳 酸菌飲料”などを選ぶ割合もそれほど高くもないことか ら, 非欠食（毎日食べる）群に比べてエネルギー不足, パワー不足が危惧されると思われた.

この久食群の人達は自宅外生に多いことから, 朝, 覚 醒する時間が遅く, 食事を摂る暇がないのであろうか. 生活リズムと朝食を摂ることの繋がりがここでみられる ようだ9)。

3）甘味嗜好と食事状況および食生活に対する意識 との関連 
表 7 食生活満足度に関わる諸要因の度合い（数量化 I 類による）

\begin{tabular}{|c|c|c|c|c|c|c|c|c|c|}
\hline \multicolumn{2}{|c|}{ 説明要因 *1 } & \multicolumn{4}{|c|}{ 男 子 (300人) } & \multicolumn{4}{|c|}{ 女 子 (298人) } \\
\hline 項 目 & カテゴリー & $\begin{array}{c}\text { カテゴリ } \\
\text { • スコア }\end{array}$ & レンジ & $\begin{array}{l}\text { 順位 } \\
\text { (レンジ) }\end{array}$ & $\begin{array}{l}\text { 偏相関 } \\
\text { 係数 } \\
\end{array}$ & $\begin{array}{c}\text { カテゴリ } \\
\text { •スコア }\end{array}$ & レンジ & \begin{tabular}{|l} 
順位 \\
(レンジ $)$
\end{tabular} & $\begin{array}{l}\text { 偏相関 } \\
\text { 係数 }\end{array}$ \\
\hline $\begin{array}{l}\text { 1. 甘い } \\
\text { お菓子の } \\
\text { 摂取頻度 }\end{array}$ & \begin{tabular}{|l} 
1.毎日 2 回以上 \\
2.毎日 1 回位 \\
$3.2 \sim 3$ 日に 1 回位 \\
$4.1 \sim 2$ 週間に 1 回位 \\
5.
\end{tabular} & $\begin{array}{r}-0.324 \\
0.088 \\
-0.045 \\
0.004 \\
0.061 \\
\end{array}$ & 0.4117 & 5 & 0.0713 & $\begin{array}{r}-0.397 \\
0.162 \\
-0.051 \\
-0.117 \\
-0.234 \\
\end{array}$ & 0.5589 & 3 & 0.1232 \\
\hline $\begin{array}{l}\text { 2. 甘い飲み } \\
\text { 物の搘好 } \\
\text { 濃度 }\end{array}$ & $\begin{array}{l}\text { 1.濃い万が好き } \\
\text { 2.やや濃い方が好き } \\
\text { 3.どちらともいえない } \\
\text { 4.やや薄い万が好き } \\
\text { 5.薄い万かか好き } \\
\end{array}$ & $\begin{array}{r}0.233 \\
0.114 \\
-0.131 \\
0.120 \\
-0.307 \\
\end{array}$ & 0.5396 & 3 & 0.1365 & $\begin{array}{r}-0.136 \\
-0.159 \\
0.003 \\
0.225 \\
-0.013 \\
\end{array}$ & 0.3841 & 6 & 0.1114 \\
\hline $\begin{array}{l}3 . \text { 朝食の } \\
\text { 摂取頻度 }\end{array}$ & $\begin{array}{l}\text { 1.每日食べる } \\
\text { 2.時々食べない } \\
\text { 3.いつも食べない }\end{array}$ & $\begin{array}{r}0.505 \\
-0.063 \\
-0.268 \\
\end{array}$ & 0.7730 & 1 & 0.2768 & $\begin{array}{r}0.304 \\
-0.411 \\
-0.466 \\
\end{array}$ & 0.7700 & 2 & 0.2882 \\
\hline $\begin{array}{l}4 . \text { 昼食の } \\
\text { 摂取頻度 }\end{array}$ & $\begin{array}{l}\text { 1.毎日食べる } \\
\text { 2.食べないがある*2 }\end{array}$ & $\begin{array}{r}0.014 \\
-0.032 \\
\end{array}$ & 0.0455 & 8 & 0.0186 & $\begin{array}{r}-0.005 \\
0.037\end{array}$ & 0.0426 & 8 & 0.0121 \\
\hline $\begin{array}{l}\text { 5.夕食の } \\
\text { 拄取頻度 }\end{array}$ & $\begin{array}{l}\text { 1.毎日食べる } \\
\text { 2.食へない恼るる2 }\end{array}$ & $\begin{array}{r}0.013 \\
-0.089 \\
\end{array}$ & 0.1021 & 7 & 0.0313 & $\begin{array}{r}0.087 \\
-0.386 \\
\end{array}$ & 0.4732 & 5 & 0.1576 \\
\hline $\begin{array}{l}6 . \text { 偏食の } \\
\text { 有無 }\end{array}$ & $\begin{array}{l}\text { 1.ほとんどない } \\
\text { 2.少しある } \\
\text { 3.非常にある } \\
\end{array}$ & $\begin{array}{r}0.033 \\
0.013 \\
-0.273 \\
\end{array}$ & 0.3062 & 6 & 0.0772 & $\begin{array}{r}0.041 \\
0.029 \\
-0.265 \\
\end{array}$ & 0.3065 & 7 & 0.0868 \\
\hline 7. 食事量 & $\begin{array}{l}\text { 1.多い } \\
\text { 2.やや多い } \\
\text { 3.人並み } \\
\text { 4.やや少ない } \\
\text { 5.少ない } \\
\end{array}$ & $\begin{array}{r}0.296 \\
0.103 \\
-0.02 \\
-0.242 \\
-0.230 \\
\end{array}$ & 0.5373 & 4 & 0.1283 & $\begin{array}{r}0.175 \\
0.249 \\
-0.042 \\
-0.145 \\
-0.921 \\
\end{array}$ & 1.1699 & 1 & 0.1391 \\
\hline $\begin{array}{l}\text { 8.栄養 } \\
\text { バランス }\end{array}$ & $\begin{array}{l}\text { 1.よく考えている } \\
\text { 2.考えている } \\
\text { 3.あまり考えていない } \\
\text { 4.全く考えていない } \\
\end{array}$ & $\begin{array}{r}-0.523 \\
0.101 \\
-0.078 \\
0.202\end{array}$ & 0.7249 & 2 & 0.1417 & $\begin{array}{r}0.294 \\
0.050 \\
-0.081 \\
-0.245 \\
\end{array}$ & 0.5387 & 4 & 0.091 \\
\hline
\end{tabular}

*1 目的要因は食生活満足度とし, 表 2 に示したカテゴリーを数量化した. また, 説明要因の各カテゴリ一人数は表 2 示してある通りである.

*2 カテゴリー統合を行った.

表 5 に示したように，女子においては「甘味飲料の摂 取頻度」と「偏食の有無」とのクロスが有意であり（ $<0.01)$, および「甘い飲久物の嘫好濃度」と「栄養バ ランス」とのクロスが有意であった（ $\mathrm{p}<0.01 ）$ ので, それらのクロスを図 5 に示した．有意であった女子につ いてみると，図5-1より，偏食が少ない群ほど，「甘味飲 料の摄取頻度」は低かった．そして図5-2より，栄盖バ ランスをよく考えている群ほど,「甘い飲み物の嗜好濃 度」では薄い方の味を好むようであった。

また表 5 より，「主な飲及物」とのクロスで有意であ った項目は，「偏食の有無」（女子に抒いて， p <0.01）, 「栄養バランス」（女子において, $\mathrm{p}<0.05)$, 「食生活 の満足度」（女子に扔いて， p <0.05）といずれも女子 であった. そのうちの「主な飲反物」と「栄盖バランス」
のクロスは表 6 に示したのであるが，女子で栄養バラン スを考えている群は「主な飲反物」としては“甘味飲料” を選ぶ割合は低く, “日本茶”, “中国茶”, “牛乳”を選 ぶ人は多かった。

\section{（4）「食生活の満足度」に関わる甘味嗜好の度合い}

「食生活の満足度」は, 諸々の因子のからみがあって 評価される，いわば総合評価と考えられよう。そこで 「食生活の満足度」に, 表 2 に示した甘味嗜好と三食の 摂取頻度, 食事状況, および栄養意識がどれ位, 関与し ているかを把握するため, 数量化 I 類により, 「食生活 の満足度」を目的要因に, 表 2 のそれら 8 項目を説明要 因として分析した結果を表 7 に示した.

「食生活の満足度」に対して, カテゴリー・スコアが 正の大きな值で関与しているものとして, 男女共通にみ 
られたカテゴリーは，「朝食の摂取頻度」の“毎日食べ る”と「食事量」の“多い”，“やや多い”などであった． それに対し，「食生活の満足度」にカテゴリー・スコア が負の大きな值で関与しているものとして, 男女共通に みられたカテゴリーは「朝食の摂取頻度」の“いつも食 べない”，「偏食の有無」の“非常にある”,「食事量」の “少ない”，そして「甘いお菓子の摂取頻度」の “毎日 2 回以上”などであった。ここで注目したいのは，甘い 扔菓子の摂取頻度が非常に高い人達は「食生活の満足度」 においては負，すなわち食生活に不満であるということ である.しかし甘いお菓子を“毎日 1 回位”の摂取頻度 では男女ともに「食生活の満足度」に正に関与している ことから，食生活が充実していれば甘いお菓子を“毎日 2 回以上”も摂ることはないのだろうと推察された.

一方,「食生活の満足度」に対するカテゴリー・スコ アが，男女において正負と反対であったカテゴリーは， 「栄着のバランス」の“よく考える”であり，それは男 子では負, 女子では正であり，栄養に対する性差が表机 ていた．また「甘い飲反物の嗜好濃度」での“濃い方が 好き”については，男子では正に，女子では負であった ことであるが，これは若者の身体生理に基づいた嗜好の 表れと考えられだ)。

説明要因の各項目が「食生活の満足度」に関与する度 合いは，レンジの值の大きさで示されるが，それによる と男子では，1位は「朝食の摂取頻度」，2 位は「栄養 のバランス」, 3 位は「甘い飲反物の嗜好濃度」であっ た。一方，女子では，1位は「食事量」，2位は「朝食 の摂取頻度」, 3 位は「甘い拈菓子の摂取頻度」となっ た.

これより男女とも「食生活の満足度」に「朝食の摂取 頻度」の関与が大きく, 朝食を “毎日食べる”ことが満 足に, “いつも食べない”ことが不満に関係することが 分かった．ところが甘味嗜好の「食生活の満足度」に関 わる度合いについては「朝食の摂取頻度」ほどには強く なかった。 甘味赀好のうち,「甘い抢菓子の摂取頻度」 では “毎日 2 回以上”もの摂取頻度が高いことは, 食生 活の満足度に繋がらないこと，そして「甘い飲反物の嗜 好濃度」では，男女の喏好が分かれ，男子は“濃い方が 好き”，女子は “やや薄い方が好き”とする群が食生活 の満足度は高いことなどが示された.

以上より, 食生活において, 朝食を摄取することの重 要さが再認識されたが, 今後の課題としてはこの「朝食 の摂取頻度」に関係する要因を洗いだし分析することで ある。

\section{要約}

若い世代について, 甘味嗜好が食生活状況・意識とい かに関わるかを調べるため, 男女大学生（男子 300 人, 女子 298 人) に対してアンケート調査を行い, 分析した 結果は次の通りである.

1）甘味嗜好については,「甘いお菓子の摂取頻度」 は具体的な 6 種類の打菓子の摂取頻度と強く相関した. また「甘い飲み物の嗜好濃度」は具体的な甘い飲久物に 対する嗜好度と強く相関した。

2）甘味嗜好に関連して，間食理由を調べたところ, 生理的な理由はもちろん多いが, 明確な理由がないもの もかなりあり, 男女間の回答数の分布には有意な差 ( $\mathrm{p}$ く0.01）があった。 また主な飲み物についても，男子は 甘味飲料, 女子は日本茶とする人が極めて多く, 男女間 に有意な差 $(\mathrm{p}<0.01)$ があった.

3） 甘味嗜好と居住形態との関連については，それ程 強くはないが, 男女ともに自宅生群は自宅外生群に比べ て,「甘いお菓子の摂取頻度」はむしろ高い傾向がみら れた。 また運動部活動群はそれ以外の群よりも「甘味飲 料の摂取頻度」は高く，そのことが男子では有意であっ た。

4） 甘味嗜好と三食の食事の拄取頻度との関連につい ては, それ程強くはなかった。 三食の中, 朝食を摂取す る頻度は最も低く, 特に男子で朝食を“いつも食べない” 人は $41.3 \%$ も多くいた，その人達は朝食を“毎日食べる” 人達に比べて, 食事のみならず甘いお菓子打よび甘味飲 料の摄取頻度も低く, エネルギー不足が危惧された。

5）甘味嗜好と食生活状況・意識との関連については, 女子において, 偏食が少ない群ほど「甘味飲料の摂取頻 度」は有意に低く，また栄盖バランスをよく考えている 群ほど,「甘い飲久物の嗜好濃度」は薄い方を有意に好 んだ.

6）数量化 1 類の分析により,「食生活の満足度」に 甘味喍好が関わる度合いは「朝食の摂取頻度」や「栄養 バランス」ほどには強くなかった。「甘い打菓子の摂取 頻度」の非常に高い群はむしろ「食生活の満足度」は低 かった．また「甘い飲み物の嘫好濃度」の「食生活の満 足度」への関わりは男女に扔いて正負が逆となり,すな わち男子では甘味の濃い方を好む群, 女子では甘味のや や薄い方を好む群は「食生活の満足度」は高かった。

\section{文 献}

1）岡本佳子, 藤本重子：下宿大学生の食生活と健康に関す 
る意識調査, 栄養学雑誌, 48, 63〜 71（1.990)

2）伊海公子, 坂本裕子, 三好正満 : 下宿女子学生の生活環 境と食生活型, 栄養学雑誌, 55，239～251（1997）

3）大河原悦子, 小泉直子, 藤木晴美, 菅陽子, 田中久美子, 浦畑育生, 香月文子 : 男女学生のライフスタイルと健康と の関連, 栄養学雑誌, 52, 173 189 (1994)

4）加藤征江, 永田佳子, 井川明美 : 大学生の塩味または甘 味に対する味覚意識と味嗜好, 調理科学, $25,39 \sim 46$ (1992)

5）加藤征江, 井藤早苗, 浦上紀子 : 青少年についての塩味 と甘味の飲物の味嗜好について, 富山大学教育学部紀要, 第51号，35〜44（1997）
6) 菅民郎：多変量解析の実践 (下), 現代数学社, 京都, pp. 2〜38 (1993)

7）厚生省保険医療局監修: 平成10年版国民栄責の現状一平 成 8 年国民栄養調查成績, 第一出版, 東京, pp.93 94 (1998)

8）厚生省保険医療局監修: 平成10年版国民栄養の現状一平 成 8 年国民栄養調査成績, 第一出版, 東京, p.127（1998）

9）平井美穂，神川康子：子どもたちの生活リズムの実態と その問題点, 富山大学教育学部研究論集, 第 2 号, $35 \sim 42$ (1999) 